\section{Effects ofContamination byHemostatic Agents and Use of Cleaning Agent on Etch-and-Rinse Dentin Bond Strength}

César Rogério Pucci ${ }^{1}$, Rodrigo Maximo de Araújo을 Ana Julia Farias de Lacerda1, Mirella Anjos de Souza1, Maria Filomena Rocha Lima Huhtala1, Fernanda Alves Feitosa ${ }^{1}$

\begin{abstract}
The aim of this study was to evaluate the influence of contamination by hemostatic agents and rinsing with chlorhexidine on bond strength between dentin and resin composite. Ninety-six bovine teeth were sectioned to expose a flat dentin surface area. A standardized cavity with $2.0 \mathrm{~mm}$ in thickness, superficial diameter of $4.0 \mathrm{~mm}$ and bottom diameter of $3.0 \mathrm{~mm}$ was prepared with a diamond bur in each dentin specimen. The teeth were divided into four groups according to the hemostatic employed: G1: control; G2: use of ViscoStat, Ultradent; G3: Hemosthasegel, FGM; and G4: Hemostop, Dentsply. The groups were divided into two subgroups according to the cleaning protocol method $(n=12)$ : A: without any further cleaning; and B: cleaning with chlorhexidine at $0.2 \%$. All cavities were filled using a dentin adhesive and a resin composite, following the manufacturer's instructions. After $24 \mathrm{~h}$, the specimens were aged by thermal and mechanical cycling. The bond strength was determined by the push out bond test (MPa), Statistical analysis was performed using two-way ANOVA and Tukey test $(p<0.05)$. Statistically significant differences were detected among all groups treated with hemostatic agents and the control group. The post-hoc test showed that cleaning the cavity with chlorhexidine significantly improves the bond strength between dentin and resin composite. Our results suggested that the use of chlorhexidine can reestablish the bond strength between dentin and resin composite when a hemostatic agent was applied.
\end{abstract}

\author{
'Department of Restorative Dentistry, \\ Institute of Science and Technology, \\ UNESP - Univ Estadual Paulista, \\ São José dos Campos, SP, Brazil \\ ${ }^{2}$ Department of Dental Materials \\ and Prosthodontics, Institute of \\ Science and Technology, UNESP \\ - Univ Estadual Paulista, São \\ José dos Campos, SP, Brazil
}

Correspondence: Fernanda Alves Feitosa, Avenida Engenheiro Francisco José Longo, 777, Jardim São Dimas, 12245-000 São José dos Campos, SP, Brasil. Tel:+55-12-3947-9048. e-mail: fernanda.feitosa@fosjc.unesp.br

Key Words: bond strength, hemostatic agents, chlorhexidine.

\section{Introduction}

The bond strength between dentin and resin composite restoration can be influenced by the quality of the hybrid layer (1). In order to achieve an adequate hybrid layer and a longer lasting composite restoration, it is necessary to avoid the contamination of the prepared dentin by internal agents, such as salivary and gingival fluids and blood or external agents such as the lubricating oil of high speed and hemostatic agents $(2,3)$.

During the clinical procedure the rubber dam serves as a physical barrier preventing external fluids and avoiding saliva and/or blood contamination. However, there are situations in which the use of the rubber dam is impractical, such as in intrasulcular cavities, or total crown cementation under the same conditions. In these situations, it is often used gingival retraction cords and hemostatic agents to control the flow of gingival fluid and the blood contamination on the prepared dentin, which could decrease the bond strength during the restorative procedure (4-7). Hemostatic agent (aluminum chloride and ferric sulfate-based) residues induce changes in the enamel and dentin surface, harming the bond results and restoration quality $(5,8-11)$. In addition, during the cavity rinsing, after acid etching, the gingival retraction cord is saturated with the hemostatic agent. It is important to observe that the saliva doesn't make contact with the saturated cord, which could cause water penetrating into the dentin tubules and onto the dentin matrix.

Consequently, this hemostatic residue cannot be completely removed by rinsing with wate before application of the adhesive system. Among the cleaning agents suggested by the literature, chlorhexidine is an effective antimicrobial agent across a broad-spectrum, widely used in the treatment of oral diseases. Its antibacterial efficiency is comparable with that of sodium hypochlorite. Chlorhexidine potential as a matrix metalloproteinases (MMPs) inhibitor has been reported (18). MMPs are derived from proteolytic enzymes endopeptidases, calcium and zinc-dependent, that have been trapped within the mineralized dentin matrix since the time of tooth development (13-16). They present the metabolic activity of degradation and remodeling of various types of collagen fibers $(6,17)$. Restorative dentistry studies has shown long-term failures attributed to collagen degradation caused by failures during the hybrid layer, resulting in degradation at the bond interface (12). This deterioration appears to be accelerated by the action of MMPs of self-etching and total-etch adhesives. 
Based on this information, the aim of the present study was to evaluate the effect of different hemostatic agents, followed by chlorhexidine cleaning on the bond strength between dentin and resin composite.

\section{Material and Methods}

Table 1 list the commercial brand, manufacturer and composition of all materials tested in the study.

\section{Dentin Specimen Preparation}

Ninety-six recently extracted bovine teeth were selected. The incisal portion $(\sim 4 \mathrm{~mm})$ were sectioned and eliminated using a flexible diamond disc (Model 1802.7015. KG Sorensen, Sao Paulo, SP, Brazil), $9 \mathrm{~mm}$ of the middle third was delimited and the cervical third and root were discarded. With the purpose of eliminating the enamel from the specimen, a cut was made in the mesio-distal direction, exposing the dentin of the internal surface, so that the external surface remains covered with enamel. Flat blocks dentin specimens with at least $2 \mathrm{~mm}$ of thickness, superficial diameter of $4.0 \mathrm{~mm}$ and bottom diameter of 3.0

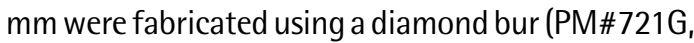
KG Sorensen, Sao Paulo, SP, Brazil) coupled to a high speed handpiece (Kavo Extra Torque 600, Kavo, São Paulo, Brazil). The cavity volume was calculated to be $19.33 \mathrm{~mm}^{3}$.

\section{Dentin Surface Treatment with the Hemostatic Agent and Cleaning Protocol}

The internal dentin was etched with 37\% phosphoric acid for $15 \mathrm{~s}$ (Magic Acid; Vigodent, Rio de Janeiro, RJ, Brazil) rinsed with water and air-dried following the manufacturer's instructions.

The samples were randomly divided among the different groups ( $n=12)$, as illustrated in Figure 1 . For each group submitted to contamination, the hemostatic agent was applied using a dedicated instrument to spread the material on the dentin surface. After $15 \mathrm{~s}$ the hemostatic was removed from dentin surface with gauze. The dentin samples were cleaned according to the group: the chlorhexidine rinsing was performed using a syringe containing $50 \mathrm{~mL}$ of the solution and dried with absorbent paper.

\section{Bonding Protocol}

After each treatment, the adhesive system (Adper Single Bond 2; 3M ESPE, St. Paul, MN, USA - Batch Number \#N289126BR) was applied with a microbrush on the entire sample surface for $15 \mathrm{~s}$ and polymerized for $10 \mathrm{~s}$ (Radii cal; SDI Brasil Indústria e Comércio, São Paulo, SP, Brazil), following the manufacturer's instructions. Specimens were submitted to the finishing and polishing procedures using abrasive papers (Extec, Enfield, CT, USA) of decreasing granulation (\#600 and \#1200) with diamond pastes (Diamond Gloss 1, KG Sorensen, São Paulo, Brazil) using felt discs (Arotec, Cotia, São Paulo, Brazil). The cavities were restored with a single increment of a resin composite (Filtek Z-350XT; 3M ESPE) and light activated for $20 \mathrm{~s}(1200 \mathrm{~mW} /$ $\mathrm{cm}^{2}$ ), following the manufacturer's instructions. All samples were stored at $37{ }^{\circ} \mathrm{C}$ for $24 \mathrm{~h}$ at $100 \%$ humidity.

All specimens were submitted to thermomechanical aging $(100,000 \times, 4 \mathrm{~Hz}$, load of $60 \mathrm{~N})$ and $500 \times$ thermal cycles

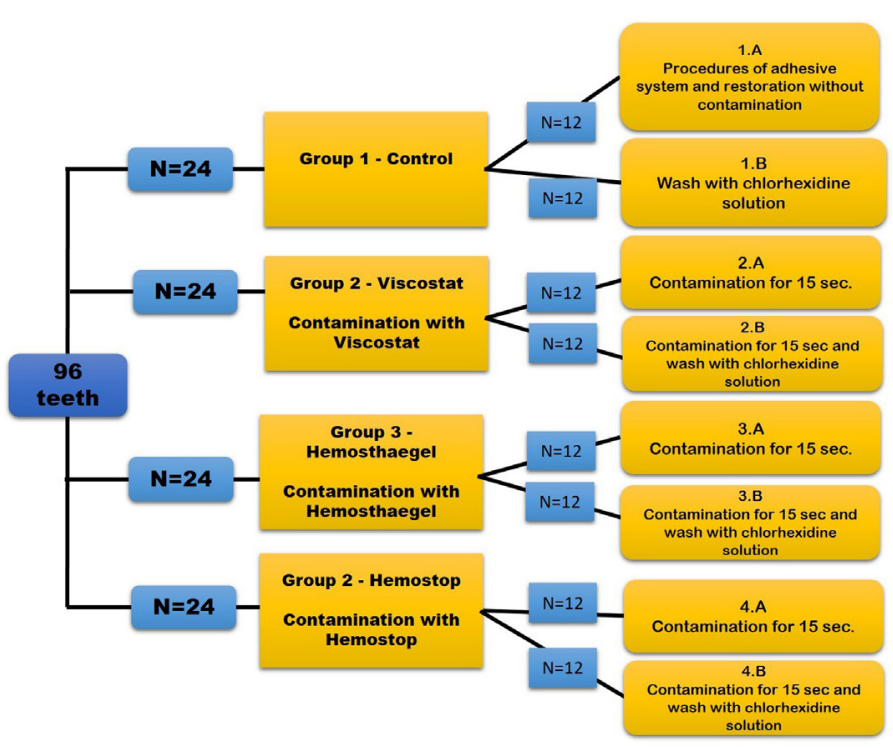

Figure 1. Experimental design

Table 1. Materials used in study, commercial brand, manufacturer and composition

\begin{tabular}{|c|c|c|c|}
\hline Material & Commercial brand & Manufacturer & Composition \\
\hline $\begin{array}{l}\text { Aluminum } \\
\text { chloride }\end{array}$ & Hemostop & $\begin{array}{l}\text { Dentsply Indústria e } \\
\text { Comércio Ltda, RJ, Brazil }\end{array}$ & $\begin{array}{l}95 \% \text { ethyl alcohol, isopropyl alcohol, aluminum chloride pa } \\
13 \% \text { to } 15 \% \text {, hydroxyquinoline sulfate, propylene glycol }\end{array}$ \\
\hline Ferric sulfate & Viscostat & $\begin{array}{l}\text { Ultradent do Brasil produtos } \\
\text { odontológicos, Indaiatuba, SP, Brasil }\end{array}$ & $20 \%$ ferric sulfate \\
\hline $\begin{array}{l}\text { Aluminum } \\
\text { chloride }\end{array}$ & Hemosthasegel & Dentscare Ltda, Joinville, SC, Brasil & $\begin{array}{l}\text { 25\% aluminum chloride, deionized water, sodium } \\
\text { hydroxide, thickener and humidifier }\end{array}$ \\
\hline Chlorhexidine & Manipulated product & Manipulated product & $0.2 \%$ chlorhexidine \\
\hline
\end{tabular}


(30 s baths at $5{ }^{\circ} \mathrm{C}, 37^{\circ} \mathrm{C}$ and $55^{\circ} \mathrm{C}$ ) (Erios 37000; Erios, São Paulo, SP, Brazil) simultaneously in thermomechanical cycling machine. During the mechanical test, specimens were placed in machine by means of a metal part containing a central orifice, in which the specimen was positioned to the base of the machine. In the top region of the machine a metal tip was attached, which exerted a compression force in the region with the smallest diameter of the restoration. The dentin block remained with the smaller cavity diameter facing up, in contact with the tip of the universal test machine. The load was applied from the smallest diameter towards the largest diameter until the resin composite increment was dislodged, or fracture of the specimen occurred.

\section{Push Out Mechanical Test}

For the push-out test an adapted metal cylinder $\left(\varnothing_{\text {extremity }}=0.85 \mathrm{~mm}\right)$ induced the load on the central portion of the resin block (no load was applied on the dentin surface). The test was performed in a universal testing machine (EMIC model DI-1000; EMIC, Curitiba, PR, Brazil) at speed of $1 \mathrm{~mm} / \mathrm{min}$.

$\therefore$ Calculation of Bond Area (A) of Specimens

A formula was applied to calculate the lateral area of the figure of a straight trunk with a circular cone with parallel bases.

The bond strength was obtained by the formula $\mathbf{o}=$ $C / A$, where $C=$ load for test specimen rupture $(N), A=$ interfacial area $\left(\mathrm{mm}^{2}\right)$. Thus, $A=\pi . g .\left(R_{1}+R_{2}\right)$, where, $A=$ interfacial area, $\pi=3.14, g=$ slant height, $R_{1}=$ radius of smaller base, $R_{2}=$ radius of larger base, $h=$ height of section. To calculate the slant height of the lateral portion of the

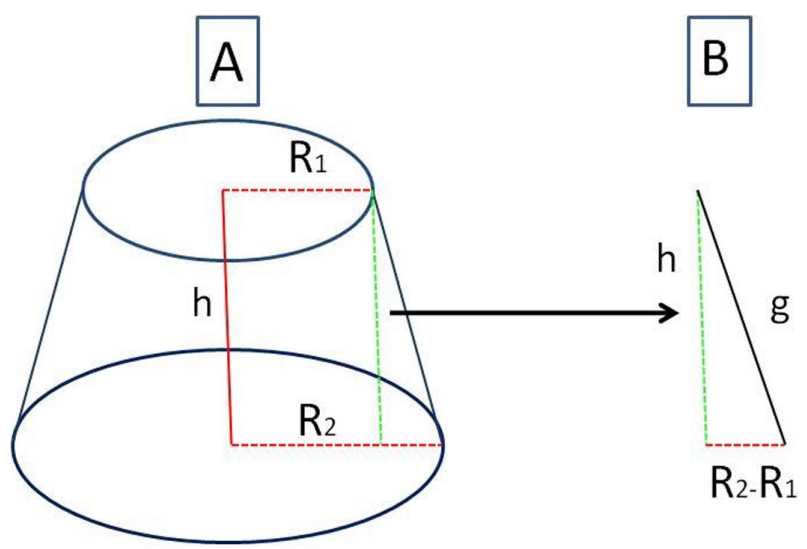

Figure 2. (A) Diagrammatic drawing corresponding to the internal section of the cavity. Geometrical figure of a straight trunk of a circular cone with parallel bases, where $\mathrm{h}$ is the specimen height, $\mathrm{R} 1$ is the radius of the smaller base and $\mathrm{R} 2$ the radius of the larger base; (B) Geometrical figure (triangle) to calculate the slant height $g$ of the cone. cone "g", the Pythagorean Theorem was used - "the square of the hypotenuse is equal to the sum of the squares of the other two sides". Therefore, to calculate " $g$ ", the following formula was used: $g^{2}=h^{2}+\left[R_{2} R_{1}\right]^{2}$.

The values of $R_{1}$ and $R_{2}$ were obtained by measuring the diameters of the smaller and larger bases respectively. These diameters and the height $h$ of the test specimen were measured after trial with a digital caliper (Starret 727; Starret, Itu, SP, Brazil) (Fig. 2). After that, all the tested samples were analyzed using a stereomicroscope and classified as; adhesive (between dentin-adhesive and resin composite or between dentin-adhesive and dentin), cohesive in dentin or cohesive in resin composite.

The results of push-out test (MPa) were submitted to two-way ANOVA $(p<0.05)$, followed by Tukey's test.

\section{Results}

The means and standard deviation of bond strength obtained after the push-out test results are shown in Table 2. The results of contamination with hemostatic agent, cleaning with chlorhexidine and the intercept of these factors were submitted to two-way ANOVA $(p=5 \%)$.

It was observed that there was statistical significant difference for the factors contamination with hemostatic agent $(p<0.0001)$, cleaning with Chlorhexidine $(p<0.0001)$ and the intercept of them $(p<0.0001)$.

A post-hoc Tukey test showed statistically significant differences among the Control groups, Hemosthaegel and Viscostat groups.

For chlorhexidine, the comparative analysis showed

Table 2. Results of push out bond strength of each evaluated group: Means (MPa),standard deviations and Tukey's test results

\begin{tabular}{|c|c|c|c|}
\hline \multicolumn{3}{|c|}{ Experimental Groups } & \multirow{2}{*}{$\frac{\text { Mean (SD) }}{2.07(0.60)^{\mathrm{A}}}$} \\
\hline G1A & Control & $\begin{array}{l}\text { Without cleaning } \\
\text { with chlorhexidine }\end{array}$ & \\
\hline G1B & Control & $\begin{array}{l}\text { Cleaning with } \\
\text { chlorhexidine }\end{array}$ & $1.78(0.25)^{\mathrm{AB}}$ \\
\hline G2A & Viscostat & $\begin{array}{l}\text { Without cleaning } \\
\text { with chlorhexidine }\end{array}$ & $0.83(0.15)^{\mathrm{CD}}$ \\
\hline G2B & Viscostat & $\begin{array}{l}\text { Cleaning with } \\
\text { chlorhexidine }\end{array}$ & $1.97(0.46)^{\mathrm{AB}}$ \\
\hline G3A & Hemosthasegel & $\begin{array}{l}\text { Without cleaning } \\
\text { with chlorhexidine }\end{array}$ & $1.14(0.13)^{\mathrm{C}}$ \\
\hline G3B & Hemosthasegel & $\begin{array}{l}\text { Cleaning with } \\
\text { chlorhexidine }\end{array}$ & $1.89(0.33)^{\mathrm{AB}}$ \\
\hline G4A & Hemostop & $\begin{array}{l}\text { Without cleaning } \\
\text { with chlorhexidine }\end{array}$ & $1.56(0.46)^{\mathrm{B}}$ \\
\hline G4B & Hemostop & $\begin{array}{l}\text { Cleaning with } \\
\text { chlorhexidine }\end{array}$ & $1.94(0.34) \mathrm{AB}$ \\
\hline
\end{tabular}

Different letters indicate statistically significant difference between groups 
statistically significant differences between the push-out resistance in the cavities cleaned with chlorhexidine or not. All the analyzed failures were classified as adhesive between dentin-adhesive and resin composite.

\section{Discussion}

This study confirmed the hypothesis that hemostatic agents have a negative influence on the bond strength between composite resin restorations and dentin. In addition, cleaning with chlorhexidine after contamination with hemostatic agents recovers the bond strength of restorations (Table 2). Among the evaluated hemostatic agents, the contamination with ferric sulfate (Viscostat) resulted in the lowest values of bond strength, different from a previous report (8), where ferric sulfate-based hemostatic contamination showed no significant deleterious effect on the bond strength between dentin and resin composite.

A previous study (19) used human dentin in Class V cavities contaminated with sulphate-based hemostatic and restored with two different adhesive systems (fifth and seventh generations). Followed by resin-composite with no further cleaning treatment both adhesives presented greater marginal microleakage when compared to the control group, without contamination (19). However, the same authors (19) have reported that the viscous nature of the ferric sulfate-based hemostatic agent made its removal by acid etching more difficult. The hemostatic composition has been reported to promote coagulation of proteins present in the dentinal fluid, and this associate with the ineffective penetration of the adhesive systems, was consequently responsible for the bond failure.

Another study (9) observed a reduction in bond strength when using samples contaminated with $25 \%$ aluminum chloride $\left(\mathrm{AlCl}_{3}\right)$ and a self-etch adhesive, however, when they use a conventional three-step dentin adhesive, the bond strength remained similar to that of the control group, without contamination. A different study (3) that evaluated the influence of $\mathrm{AlCl}_{3}$ based hemostatic agents on marginal microleakage on Class $\mathrm{V}$ cavity (bovine teeth) after restoration with resin composite obtained similar results, with reduced bond strength after contamination.

The present study suggests that cleaning the dentin with chlorhexidine can reestablish part of the bond strength after contamination with hemostatic agents. Chlorhexidine has bactericidal and bacteriostatic properties that have made it a cleaning agent widely used to clean cavities, root canals and for reducing and stabilizing the oral microbiota before dental procedure. One of the chlorhexidine properties that have triggered a large number of studies, is its capacity to inhibit the MMPs present in dentin (20). These MMPs may be activated during acid etching, which results in a drop of $\mathrm{pH}$ and presence of metal ions such as $\mathrm{Zn}^{2+}$ and $\mathrm{Ca}^{2+}$, thereby degrading the exposed collagen (18).

Previous studies $(21,22)$ observed that chlorhexidine did not present a negative impact on the bond strength of resin composite restorations when self-etching and conventional adhesive systems were applied. In the present study it was observed that the use of chlorhexidine after contamination with hemostatic agents considerably reestablishes the bond strength of resin composite restorations for all the hemostatic agents used, however, all the results were lower than those of the bond strength values of the control group. The Control group cleansed with chlorhexidine shows lower bond strength medians when compared to the Control group without cleansing, nonetheless there were no significant differences between these results.

Use of chlorhexidine is considered a benefit in slowing down the rate of degradation of bond interface between resin and dentin (23). Studies (18) are showing that after the application of chlorhexidine, collagen fibril networks of hybrid layers maintain their normal structure and integrity. Progressive degradation was shown when chlorhexidine was not applied. This coincides with a study (6) that demonstrated that chlorhexidine solutions were capable of inhibiting the MMPs, and reducing the solubilization of collagen fibrils in an aqueous medium.

Chlorhexidine is a cationic detergent with high spectrum antimicrobial activity. As a result of its detergent application, chlorhexidine could be responsible for removing the hemostatic remanescent. The specimen surface analysis submitted to different challenges was not included in the present study. Further investigation will be necessary to evaluate that. In addition, chlorhexidine applied after the acid etching has shown the potential of inhibiting endogenous enzymatic activity from the dentin, improving the bond strength between the resin composite and treated dentin (24). These finds would contribute to a better adhesion between adhesive restoration and dentin during the clinical practice.

In conclusion, our findings suggests that hemostatic agents based on 13\% $\mathrm{AlCl}_{3}$ and 25\% ferric sulfate are responsible for lower values on the bond strength between dentin and composite restoration. The use of chlorhexidine as a cleaning agent before the restorative procedure reestablished the bond strength. In addition, chlorhexidine would provide a longer-lasting restoration by the mechanism of MMP inhibition mentioned above. Considering the promising bond strength results of dentin contaminated by hemostatic and cleaned with chlorhexidine, the present study concluded that the use of chlorhexidine before the restorative treatment is an excellent option during the clinical practice. 


\section{Resumo}

0 objetivo desse estudo foi avaliar a influência da contaminação por agentes hemostáticos e da lavagem com clorexidina na resistência de união entre dentina e resina composta. 96 dentes bovinos foram seccionados para a exposição de uma área plana de dentina. Em cada bloco, uma cavidade cônica de $2 \mathrm{~mm}$ de espessura, diâmetro externo de $4 \mathrm{~mm}$ e diâmetro interno de $3 \mathrm{~mm}$, foi confeccionado com uma ponta diamantada. Os dentes foram divididos em 4 grupos de acordo com o hemostático empregado, como descrito: G1- controle, G2- uso de ViscoStat - Ultradent, G3- uso de Hemosthasegel - FGM, G4- uso de Hemostop - Dentsply. Os grupos foram divididos em 2 subgrupos de acordo com o protocolo de limpeza utilizado $(n=12)$ : $A$ - nenhum agente de limpeza; B - limpeza com clorexidina $0.2 \%$. Todas as cavidades foram preenchidas utilizando adesivo dentinário e resina composta, seguindo as instruções dos fabricantes. Após $24 \mathrm{~h}$, os espécimes foram submetidos a protocolo de envelhecimento em cicladora termomecânica. A resistência de união foi determinada pelo teste mecânico de push-out (MPa), as análises estatísticas foram realizadas utilizando ANOVA 2-fatores e teste de Tukey $(p<0.05)$. Diferenças estatisticamente significativas foram detectadas entre todos os grupos tratados com agentes hemostáticos e o grupo controle. 0 teste post-hoc mostrou que a limpeza da cavidade com clorexidina aumenta significativamente a resistência de união entre dentina e resina composta. Os resultados sugerem que o uso da clorexidina pode restabelecer a resistência de união entre dentina e resina composta quando um agente hemostático é aplicado.

\section{References}

1. Nakabayashi N. The hybrid layer: a resin-dentin composite. Proceedings of the Finnish Dental Society 1992;88 Suppl 1:321-329.

2. Xie J, Powers JM, McGuckin RS. In vitro bond strength of two adhesives to enamel and dentin under normal and contaminated conditions. Dent Mat 1993;9:295-299.

3. Mohammadi N, Kimyai S, Bahari M, Pournaghi-Azar F, Mozafari A. Effect of aluminum chloride hemostatic agent on microleakage of class $\mathrm{V}$ composite resin restorations bonded with all-in-one adhesive. Med Oral Patol Oral Cirur Bucal 2012;17:841-844.

4. Carvalho Mendonça EC, Vieira SN, Kawaguchi FA, Powers J, Matos AB. Influence of blood contamination on bond strength of a self-etching system. Eur J Dent 2010;4:280-286.

5. Chaiyabutr $Y_{1}$ JC Kois. The effect of tooth-preparation cleansing protocol on the bond strength of self-adhesive resin cement to dentin contaminated with a hemostatic agent. Oper Dent 2011;36:18-26.

6. Gendron R Grenier D, Sorsa T, Mayrand D. Inhibition of the activities of matrix metalloproteinases 2, 8, and 9 by chlorhexidine. Clinical and Diagnostic Laboratory Immunology 1999;6:437-439.

7. de Oliveira Bernades K, Hilgert LA, Ribeiro AP, Garcia FC, Pereira PN. The influence of hemostatic agents on dentin and enamel surfaces and dental bonding: A systematic review. J Am Dent Assoc 2014;145:11201128.

8. Kimmes NS, Olson TL, Shaddy RS, Latta MA. Effect of ViscoStat and ViscoStat Plus on composite shear bond strength in the presence and absence of blood. J Adhes Dent 2006;8:363-366.
9. Kuphasuk W, Harnirattisai C, Senawongse $P$, Tagami J. Bond strengths of two adhesive systems to dentin contaminated with a hemostatic agent. Oper Dent 2007;32:399-405.

10. O'Keefe KL, Pinzon LM, Rivera B, Powers JM. Bond strength of composite to astringent-contaminated dentin using self-etching adhesive. Am J Dent 2005;18:168-172.

11. Sung EC, Tai ET, Chen T, Caputo AA. Effect of irrigation solutions on dentin bonding agents and restorative shear bond strength. J Prost Dent 2002;87:628-632.

12. Hebling J, Pashley DH, Tjäderhane L, Tay FR. Chlorhexidine arrests subclinical degradation of dentin hybrid layers in vivo. J Dent Res 2005;84:741-746.

13. Lehmann $N$, Debret $R$, Roméas $A$, Magloire $H$, Degrange $M$, Bleicher $F$, et al.. Self-etching increases matrix metalloproteinase expression in the dentin-pulp complex. J Dent Res 2009;88:77-82.

14. Pashley DH, Tay FR, Yiu C, Hashimoto M, Breschi L, Carvalho RM, et al.. Collagen degradation by host-derived enzymes during aging. J Dent Res 2004;83:216-221.

15. Tjäderhane L, Larjava $H$, Sorsa $T$, Uitto VJ, Larmas $M$, Salo T. The activation and function of host matrix metalloproteinases in dentin matrix breakdown in caries lesions. J Dent Res 2008;77:1622-1629.

16. van Strijp AJ, Jansen DC, DeGroot J, ten Cate JM, Everts V. Hostderived proteinases and degradation of dentine collagen in situ. Caries Research 2003;37:58-65.

17. Bourd-Boittin $K$, Fridman $R$, Fanchon $S$, Septier D, Goldberg $M$, Menashi S. Matrix metalloproteinase inhibition impairs the processing, formation and mineralization of dental tissues during mouse molar development. Exp Cell Res 2005;304:493-505.

18. Tezvergil-Mutluay A, Agee KA, Hoshika T, Carrilho M, Breschi $L$, Tjäderhane $L$, et al.. The requirement of zinc and calcium ions for functional MMP activity in demineralized dentin matrices. Dent Mat 2010;26:1059-1067.

19. Kumar P, Shenov A, Joshi S. The effect of various surface contaminants on the microleakage of two different generation bonding agents: A stereomicroscopic study. J Conserv Dent 2012;15:265-269.

20. Carrilho MR, Geraldeli S, Tay F, Goes MF, Carvalho RM, Tjäderhane L, et al.. In vivo preservation of the hybrid layer by chlorhexidine. J Dent Res 2007;86:529-533.

21. Sheikh H, Heymann HO, Swift EJ Jr, Ziemiecki TL, Ritter AV. Effect of saliva contamination and cleansing solutions on the bond strengths of self-etch adhesives to dentin. J Esthet Restor 2010;22:402-410.

22. Nishitani $Y$, Yoshiyama $M$, Wadgaonkar B, Breschi L, Mannello $F$, Mazzoni A, et al.. Activation of gelatinolytic/collagenolytic activity in dentin by self-etching adhesives. Eur J Oral Sci 2006;114:160-166.

23. Ricci HA, Sanabe ME, Souza Costa CA, Pashley DH, Hebling J. Chlorhexidine increases the longevity of in vivo resin-dentin bonds. Eur J Oral Sci 2010;118:411-416.

24. Sharafeddin $F$, Farhadpoue $H$. Evaluation of shear bond strength of total and self-etching adhesive systems after application of chlorhexidine to dentin contaminated with a hemostatic agent. J Dent (Shiraz) 2015;16:175-181.

Received March 22, 2016 Accepted August 4, 2016 